\title{
YERBILIMLERI
}

Bulletin for Earth Sciences

Yerbilimleri, 2019, 40 (1), 110-135, DOI:10.17824/yerbilimleri.500472

Hacettepe Üniversitesi Yerbilimleri Uygulama ve Araştırma Merkezi Bülteni

Bulletin of the Earth Sciences Application and Research Centre of Hacettepe University

\section{An Investigation on the Evaluation of Seismic Network and Catalogue of Regional Earthquake-Tsunami Monitoring Center (RETMC-KOERI)}

Bölgesel Deprem-Tsunami İleme ve Değerlendirme Merkezi (BDTiM-KRDAE) Sismik Ağı ve Kataloğunun Değerlendirilmesi Üzerine Bir Inceleme

\section{MUSAVVER DIDEM CAMBAZ ${ }^{1, *}{ }^{\star}$, FATIH TURHAN ${ }^{1 \mathrm{~B}}$, MEHMET YILMAZER $^{1 \mathrm{C}}$, KIVANÇ KEKOVALI $^{1 \mathrm{D}}$, ÖCAL NECMIOĞLU ${ }^{1 E}$, DOĞAN KALAFAT ${ }^{1 F}$}

${ }^{1}$ Regional Earthquake Tsunami Monitoring Center, Kandilli Observatory and Earthquake Research Institute,
Boğaziçi University, Çengelköy, İstanbul, Turkey.

Geliş (received): 21 Aralık (December) 2018 Kabul (accepted): 13 Nisan (April) 2019

\section{ABSTRACT}

Seismicity catalogs are the most important product of seismic network operating centers, especially for the earthquake hazard studies. Understanding the nature of regional catalogues has primary importance in shedding light on statistical parameters of the seismicity behavior of that given region. It is a well-known fact that artificial effects exist in the regional catalogues. Precisely determined earthquake parameters are important not only for understanding the seismicity and seismotectonics of a region, but also for providing an accurate estimation of the seismic hazard and risk parameters. In this study, we present an evaluation of the Kandilli Observatory and Earthquake Research Institute (KOERI) - Regional Earthquake Tsunami Monitoring Center (RETMC) seismicity catalog for the time duration of 2013 - 2017. We mapped the magnitude of completeness, Mc, for Turkey for the RETMC catalog. We compared the results with the Mc values of different local earthquake sequences in the region, by also considering the variations of Mc with time. Results of the study will be a reference guide for researchers who benefit from RETMC-KOERI data.

Keywords: Earthquake, Seismicity, Seismic Network, Catalogue, Turkey. https://doi.org/10.17824/yerbilimleri.500472

M. Didem CAMBAZ didem.samut@boun.edu.tr

\footnotetext{
${ }^{A}$ RETMC, Kandilli Obs. and Earthq. Res. Ins., Boğaziçi Uni., Çengelköy, İstanbul, Turkey, ORCID 0000-0001-5395-2388, didem.samut@boun.edu.tr,

${ }^{B}$ RETMC, Kandilli Obs. and Earthq. Res. Ins., Boğaziçi Uni., Çengelköy, İstanbul, Turkey, ORCID 0000-0003-4612-7421, fatih.turhan@boun.edu.tr,

${ }^{C}$ RETMC, Kandilli Obs. and Earthq. Res. Ins., Boğaziçi Uni., Çengelköy, İstanbul, Turkey, ORCID 0000-0002-1717-6059, mehmety@boun.edu.tr,

${ }^{D}$ RETMC, Kandilli Obs. and Earthq. Res. Ins., Boğaziçi Uni., Çengelköy, İstanbul, Turkey, ORCID 0000-0001-9292-7150, kekovali@boun.edu.tr,

E RETMC, Kandilli Obs. and Earthq. Res. Ins., Boğaziçi Uni., Çengelköy, İstanbul, Turkey, ORCID 0000-0002-7211-8564, ocal.necmioglu@boun.edu.tr,

F RETMC, Kandilli Obs. and Earthq. Res. Ins., Boğaziçi Uni., Çengelköy, İstanbul, Turkey, ORCID 0000-0002-4888-3311, kalafato@boun.edu.tr.
} 


\section{ÖZ}

Sismik kataloglar özellikle deprem zararı çalışmalarında, sismik ağ işleten merkezlerin en önemli ürünleridir. Bölgesel deprem kataloglarının doğasını anlamak o bölgenin sismik davranışının istatistiksel parametrelerinin üzerine ışık tutmada birincil önemdedir. Zamanla altyapının değişmesinden dolayı kataloglarda insan kaynaklı homojensizliğin ve yapay etkilerin bulunduğu iyi bilinen bir durumdur. Hassas olarak belirlenen deprem parametrelerinin sadece sismisite ve sismotektoniğin anlaşılmasında değil, sismik tehlike ve risk parametrelerinin hassas bir şekilde belirlenmesini sağlamak için de önemlidir. Bu çalışmada, Kandilli Rasathanesi ve Deprem Araştırma Enstitüsü (KRDAE) Bölgesel Deprem - Tsunami İzleme ve Değerlendirme Merkezi (BDTiM) 2013-2017 yılları arasındaki kataloğunun değerlendirilmesi sunulmuştur. BDTiM kataloğunun tüm Türkiye için bu aralıktaki tamamlılık magnitüdü (Magnitude of Completeness, Mc) belirlenmiş, Mc değerinin zamana bağlı değişiklikleri de göz önünde bulundurularak diğer lokal deprem dizilerindeki Mc değerleri ile karşılaştırılmıştır. Çalışmanın sonuçları KRDAE-BDTiM verilerinden faydalanan araştırmacılara başucu kaynağı olacaktır.

Anahtar Kelimeler: Deprem, sismisite, sismik ağ, katalog, Türkiye.

\section{INTRODUCTION}

Three major structures dominate the active tectonics of Turkey: the Hellenic-Cyprus arc, right-lateral North Anatolian Fault Zone and left-lateral East Anatolian Fault Zone. Anatolia is extruded along these intra-continental strike-slip fault zones between the converging Eurasian and Arabian plates. The western part of the Anatolian Plate is dominated by E-W trending horst and graben structures (Stampfli, 2000). The Central Anatolia forms a broad transitional tectonic zone between the extensional tectonic regime of the Western Anatolia and the collision in Eastern Anatolia (Koçyiğit et al., 2000). Turkey is surrounded by seismically active boundaries and interactions with a variety of crustal types and tectonic styles. As a result of continuous intense deformation the region comprised of diverse structures, such as suture zones, metamorphic core complexes and young orogeneses. High 
topography in the Eastern Anatolia, with an elevation of $1.5 \mathrm{~km}$ in more than half of the region, resulting from the collision of Arabian plate with Eurasia, and relatively low topography in the Western Anatolia with extension due to the subduction indicates significant variations in the crustal structures (Yılmaz et al., 1987) (Figure 1).

Western Turkey and surrounding regions form one of the most seismically active regions in the world. Seismicity in Turkey and surrounding regions is monitored by a number of different universities and institutes. However, seismology department of KOERI, RETMC with its recent name, with the network code KO (FDSN Network Code: https://doi.org/10.7914/SN/KO), has a long history. It is the oldest seismological observation center in Turkey recording, locating and archiving the earthquakes, 24/7 (Louderback, 1948; Fettahoğlu, 2012; Kalafat et al., 2017). Since 2017, RETMC is also accredited as the Tsunami Service Provider of ICG/NEAMTWS, covering Eastern Mediterranean, Aegean, Marmara and Black Seas.

Eastern Mediterranean, Aegean and Black Sea regions have been impacted by tsunamis in the past, as covered by various detailed publications (Altınok and Ersoy, 2000; Altınok et al., 2011; Ambraseys, 2009; Soloviev, 2000). Various deterministic modeling studies (Lorito et al., 2007; Necmioglu and Ozel, 2015, Tinti et al., 2005; Yalçıner et al., 2009; Yolsal-Çevikbilen and Taymaz, 2012) confirm that these regions are prone to tsunami hazard and risk, despite having a lower recurrence rates in comparison to other parts of the world, such as Pacific and Indian oceans.

After the catastrophic Erzincan earthquake in 1939, extraordinary sea disturbances were seen in several parts of Black Sea, where the sea receded in Fatsa about $50 \mathrm{~m}$ and then advanced $20 \mathrm{~m}$. In Ünye, the sea receded about $100 \mathrm{~m}$, and in Ordu about $15 \mathrm{~m}$. The initial rise of the sea level was recorded at 6 tidal stations on the northern coast of the Black Sea (Altınok et al., 2011). 
The tsunami generated by the 20 July 2017 Mw of 6.6 earthquake near Bodrum, Turkey, was a real test for KOERI's operational tsunami warning system (Haidarzadeh et al., 2017). Based on the field surveys by Yalçıner et al. (2017), a moderate tsunami was generated following the 20 July $2017 \mathrm{Mw}$ of 6.6 earthquake reaching a maximum run-up of $1.9 \mathrm{~m}$ along a dry stream at Gümbet Bay (West of Bodrum, Turkey) and producing an average run-up of $0.6 \mathrm{~m}$ in the near-field around the city of Bodrum which flooded many nearshore restaurants and damaged boats mainly in the Gümbet Bay. A maximum run-up of $1.5 \mathrm{~m}$ was observed in Kos Island.

In addition to earthquakes as tsunami sources, massive land movements, such as the Santorini event around $1600 \mathrm{BC}$, or the Fatsa tsunami triggered by the Erzincan (Turkey) earthquake in 1939 give a clear indication that the entire Eastern Mediterranean and its connected marine regions are prone to tsunami events (Necmioğlu and Özel, 2015).

The $150^{\text {th }}$ anniversary of KOERI is celebrated in 2018 and up to today numerous scientific papers have benefitted from the data and catalog of RETMC (Tan et al., 2008; Konstantinos et al, 2013; Cambaz and Mutlu, 2015; Kalafat et al., 2003, 2006, 2009, 2011; Kadirioğlu et al, 2016; Lu et al., 2018). However, there is a lack of studies documenting the homogeneity and completeness of the data set for the RETMC catalog. Seismic networks evolve, change staff, software and hardware in time. When dealing with a catalog, it is important to know the changes in the catalog, if the interesting patterns in the catalog reflect network changes rather than changes in the Earth (Wiemer, 2001). Artificial contaminations and heterogeneity reports are present in all earthquake catalogs and most of the time they introduce errors in statistical analyses of the seismicity (Gulia et al, 2012). Main motivation of this study is to address this deficiency and review the network and catalog status of RETMC while investigating the inhomogeneities, artifacts and biases that may deflect research based on this catalog. 


\section{DATA AND METHOD}

Network Development of RETMC

The historical development of the permanent seismological station installation in RETMC has a long history. Earthquake observations of KOERI date back to the devastating 1894 Istanbul earthquake. Giovanni Agamennone went to İstanbul with the invitation of Ottoman Empire in 1895 to study the 1894 earthquake in the Marmara region, and remained two years to install two seismographs in a specially constructed housing, and to instruct some young men in seismometry (Louderback, 1948; Fettahoğlu, 2012). After that, the first mechanical station was a Mainka seismograph installed in Istanbul Kandilli in 1938 (Station Code: ISK), by the government of the Republic of Turkey (http://www.isc.ac.uk/cgi-bin/stations?stacode=ISK). RETMC's stations started to be a network in the early 1970's. In 1980's MARNET radiolinked stations started being installed in the Marmara region. The first broadband seismic station (Station Code: ISP) was installed in 1996 together with the global seismological broad-band network operated by the German GeoForschungs Zentrum (GFZ) GEOFON (http://geofon.gfz-potsdam.de/doi/network/GE). Installations of broadband stations continued in 2000's in Edirne (EDRB), Van (VANB), Balıkesir (BALB) and all over Turkey. Advances in telecommunication infrastructure technology enabled the transition from leased telephone lines to real time satellite data transfer. The transition from short period stations to broadband stations happened during the same times. Operation procedures were also changed in the meantime. The number of stations increased drastically after the devastating İzmit earthquake (M7.4) in 1999. 2000's was a turning point in the operational system in RETMC in every sense. With the number of stations increasing year by year, it reached the present day amount consisting of 134 broadband, 93 strong motion and 14 short period sensors (Figure $1)$. 


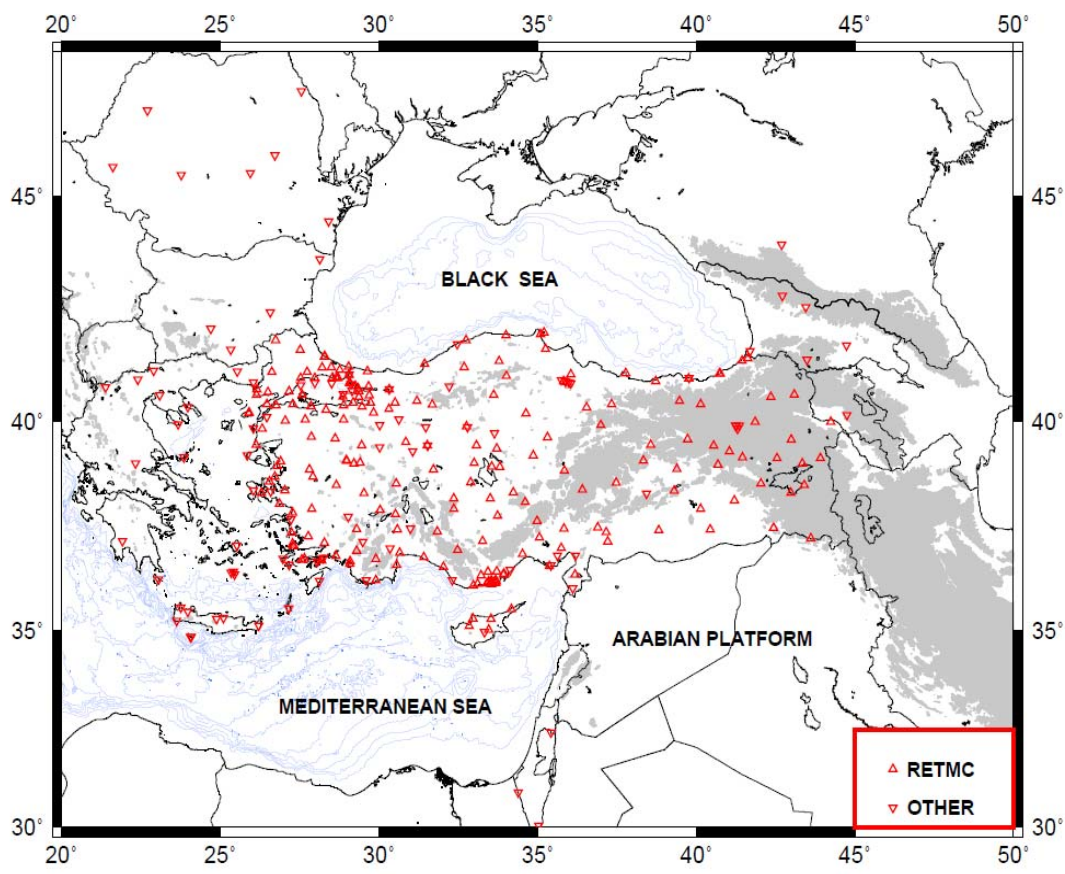

Figure 1. Station distribution used in earthquake location from RETMC network (triangles) and other stations from national and international agreements (reverse triangles) during 2013-2017. Gray shaded area shows the topography higher than $1.5 \mathrm{~km}$.

Şekil 1. 2013-2017 yılları arasında deprem lokasyonunda kullanılan, BDTiM ağından (üçgenler) ve ulusal ve uluslararası anlaşmalı diğer ağlardan (ters üçgenler) olan istasyonların dağılımı. Gri gölgelendirilmiş alan yüksekliği $1.5 \mathrm{~km}$ üzerinde olan yerleri göstermektedir.

Today RETMC is a $24 / 7$ observation center receiving real-time waveform data from 220 national sensors consisting of Broadband (BB), Accelerometer (SM), Short-period (SP) seismometers, along with the national and international seismic stations in the neighborhood area with the bilateral agreements. RETMC network is using mostly the same type of seismometers such as Güralp CMG 3T (300 s and 120 s), CMG 40T (30 s), CMG 6T (30 s), CMG 3ESPD (30 s) mainly recording at 100 sps. Relevant information on the equipment of the KOERI network can be found on the web page of RETMC (http://www.koeri.boun.edu.tr/sismo/2/tr/). The list of RETMC stations (App1), national and 
international seismic stations (App2) and the list of networks (App3) in this context, are represented in the Appendix.

\section{Seismicity Catalogue}

RETMC monitors a large area in order to detect the earthquakes both on land and surrounding seas within the area delineated by $30.00^{\circ}-48.00^{\circ} \mathrm{N}, 22.00^{\circ}-44.00^{\circ} \mathrm{E}$, for detecting the potential tsunamigenic earthquakes in the region. Over 110.000 earthquakes recorded in the last five years (01.01.2013-12.31.2017) in the region (Figure 2). Earthquake data, such as phase arrival observations, are fed through zSacWin (Yılmazer, 2012), which is a windows-based software providing easy usage of the routine earthquake location package HYPO71 (Lee and Lahr, 1972). The basic criteria for processing an earthquake is picking phases from minimum 3 stations, 5 phases with azimuthal gap smaller than $180^{\circ}$. The crustal model of Kalafat et al., (1987) is used in zSacWin for the location of earthquakes (Table 1). Early-est (Lomax and Michelini, 2012) and Seiscomp3 (Weber et al., 2007) are the automatic earthquake solution software packages used in earthquake location and tsunami studies.

\begin{tabular}{|l|r|r|r|r|}
\hline Depth $(\mathrm{km})$ & 0.00 & 5.40 & 31.60 & 89.20 \\
\hline $\mathrm{Vp}(\mathrm{km} / \mathrm{s})$ & 4.50 & 5.91 & 7.80 & 8.30 \\
\hline
\end{tabular}

Table 1. One dimensional velocity model (Kalafat et al., 1987).

Çizelge1. Bir boyutlu hız modeli (Kalafat vd., 1987). 


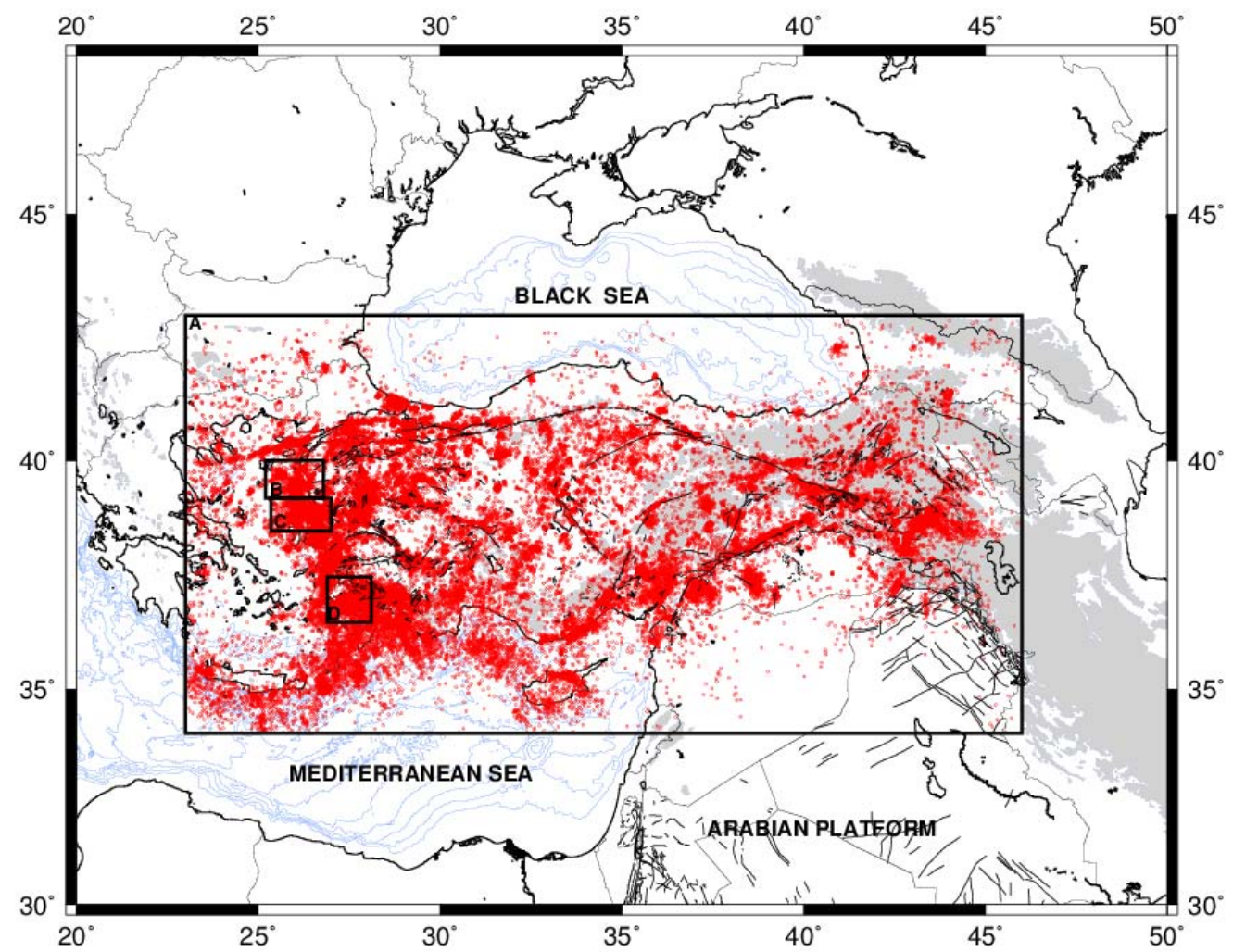

Figure 2. Seismicity map of the region with red dots representing the earthquakes recorded between 01.01.2013-12.31.2017. Black rectangles labeled A, B, C, D, enclose A) Turkey and surroundings B) Çanakkale - Ayvacık C) Lesvos-Karaburun D) Bodrum regions, described further in the text.

Şekil 2. Bölgenin sismisite haritası; kırmızı noktalar 01.01.2013-12.31.2017 arasında kayıt edilen depremleri gösterir. Siyah A, B, C, D ile işaretlenmiş dikdörtgenler A) Türkiye ve etrafı, B) Çanakkale-Ayvacık C) Lesvos-Karaburun D) Bodrum civarındaki sismisiteyi gösterir, detaylı bilgi metinin ilerleyen kısımlarında yer almaktadır.

The history of RETMC seismic catalog dates back to 1900's. However most of the earthquake data were recorded as paper seismograms prior to $1976 . \mathrm{Mb}, \mathrm{Ml}$ and $\mathrm{Mw}$ magnitudes are given as reference for the important and widely felt earthquakes (Kalafat et al., 2011). The operational procedures were changed following the improvements in computational techniques after 2000's. In this regard two milestones were: i) the transfer of 
locations from analog to digital data in 2000 and ii) the change of magnitude from duration (Md) to local (MI) in 2012.

The reported earthquake magnitude in RETMC catalog was the duration magnitude (Md) up to the end of 2011 and local magnitudes (MI) were used together with $\mathrm{Md}$ in 2012. Mainly after 2013 just MI was used in the whole catalog. After the end of 2015, moment magnitude from spectrum (MwS) has been computed and added to the catalog for the earthquakes $M \geq 3$.0. In order to prevent any confusion and ensure the uniformity, in this study, we use the seismic catalog beginning from 2013 up to the end of 2017 with local magnitude (MI) (Figure 2). Data from 2013 to 2017 have been used to compile the RETMC network earthquake catalog in the region. Due to the high rates of seismicity along the North Anatolian Fault Zone, the East Anatolian Fault Zone and the Hellenic arc, these features are more visible in the map. High amount of quarry blasts occur in the area especially at midday time. These events are removed from the seismicity map as a result of detailed study based on satellite images, night and day time hours of the events, maximum peak amplitude ratio (S/P), power ratio, and spectral amplitude ratio of the vertical component of the seismograms (Kekovalı, 2009) (Figure 3).

In this study, in order to present the RETMC catalog performance we select 93303 earthquakes for the analysis in between the time period 01.01.2013-12.31.2017 and coordinates $(34.000-43.000 \mathrm{~N}, 23.000$ - 46.000E) presented in the Figure 2 enclosed by region A. Figure 4-7 show the statistical analysis performed by using the ZMAP software (Weimer, 2001). Figure 4 shows the time histogram of the 


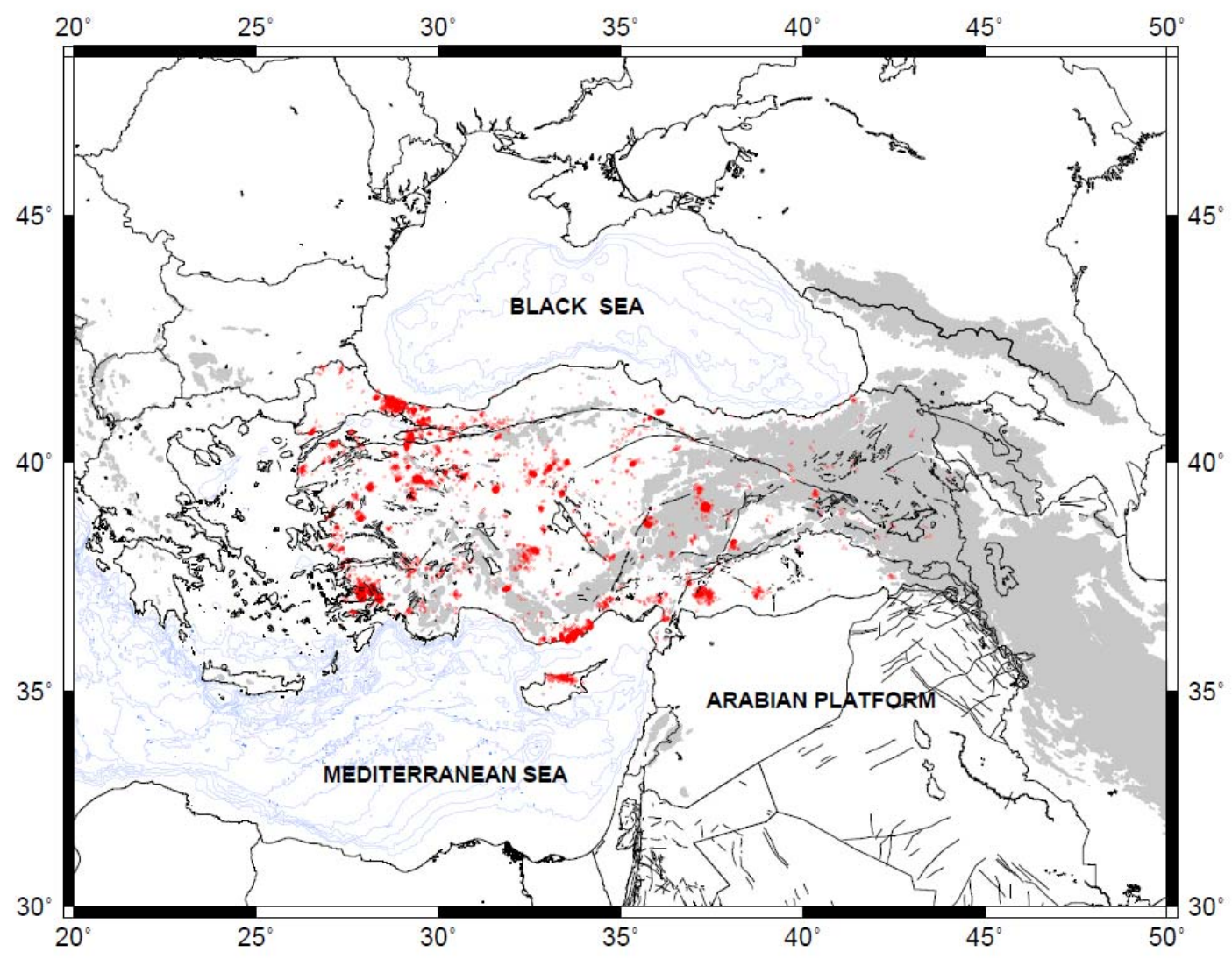

Figure 3. Distribution of quarry blasts in the region depicted using the methodology proposed by Kekovalı et al. (2009).

Şekil 3. Bölgede Kekovalı vd. (2009) tarafından önerilen metot ile belirlenen taşocaklarının dağılımı.

earthquakes. The seismicity rate is mostly constant around 1000 per month in a routine time. But the seismicity can also increase up to tenfold as seen after the large earthquakes that occurred in 2017. This increase strongly indicates that there is not any homogeneous distribution in the locations of earthquakes. Four moderate earthquakes of magnitudes $M w=5.4, M w=5.3, M w=5.3$ and $M w=5.2$ occurred within a week in Çanakkale in February 2017. These moderate earthquakes were followed by an intense aftershock activity in the following months reaching up to thousands of earthquakes. Following these consecutive events, Mw=6.3 Lesvos earthquake occurred in 12.06.2017. As a final event of these series 
Gökova earthquake $\mathrm{Mw}=6.6$ occurred with an almost ten thousand earthquake activity following the main shock.

Significant increases in the number of earthquakes can be traced in the magnitude histogram of the catalog. Figure 5 presents the hour histogram of the catalog. The enhanced ratio (day time - night time events) is generally the indicative of quarry blasts contamination that often remain in the data regardless of the network operation efforts (Wiemer and Baer, 2000; Wiemer, 2001). The decrease in daytime hours with respect to night time hours can be due to the increased noise at the recording stations (Chouliaras, 2009). Although an analysis is performed for the discrimination of events and quarry blasts, there is still an amount of increase in the number of events in the midday time which may be an indicator of that the quarry blasts are still leaking into the catalog. Figure 6 shows that most of the earthquakes have depth values less than $30 \mathrm{~km}$. Large amount of the earthquakes occur at depth ranges of 5-20 km. Magnitude histogram in Figure 7 indicates that earthquakes close to magnitude $\mathrm{M}=0$ are detectable in the catalog. Figure 7 also shows that the magnitude of completeness is generally

$M=2$

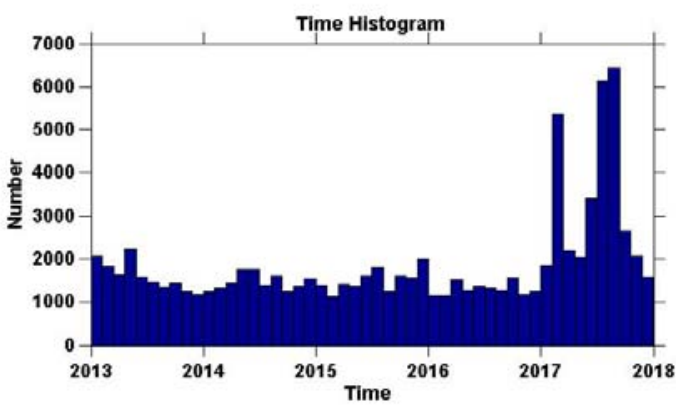

Figure 4. Earthquake-time histogram. Şekil 4. Deprem-zaman histogramı. for the catalog.

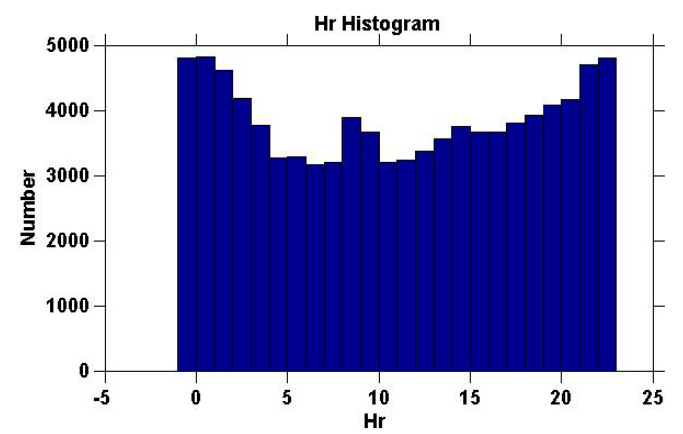

Figure 5. Earthquake-hour histogram.

Şekil 5. Deprem-saat histogramı. 


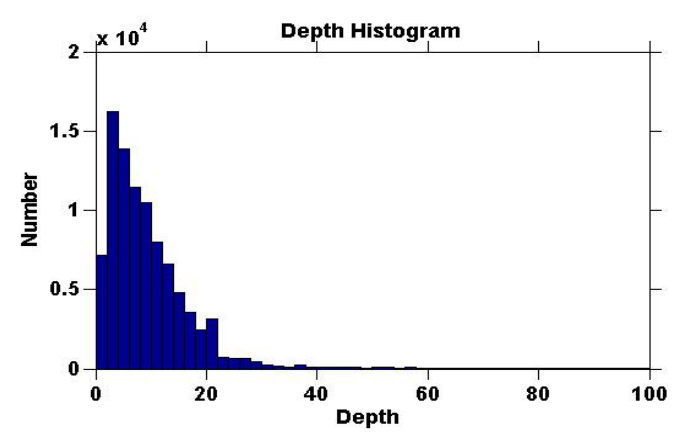

Figure 6. Earthquake-depth histogram.

Şekil 6. Deprem-derinlik histogramı.

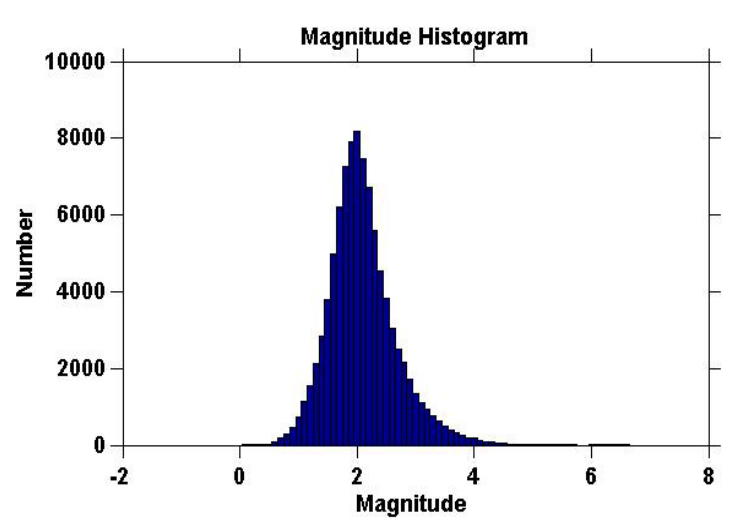

Figure 7. Earthquake-magnitude histogram.

Şekil 7. Deprem-büyüklük histogramı.

\section{Magnitude of Completeness}

Magnitude of completeness (Mc) is a critical parameter for seismicity, b value studies and hazard analysis. Mc is simply the lowest magnitude above which all events can be considered to be fully detected (Wiemer and Wyss, 2000). It varies as a function of space and time but also varies with artificial changes such as network configuration and magnitude estimation methods. Estimation of Mc for instrumental earthquake catalogs is an essential and compulsory step for any seismicity analysis (Mignan and Woessner, 2012).

Estimation of $M_{\mathrm{c}}$ is based on the assumption that, for a given volume, a simple power law can approximate the frequency magnitude distribution (Ishimoto and lida, 1939; Gutenberg and Richter, 1944) which describes the relationship between the frequency of occurrence and magnitude of earthquakes:

$\log _{10} N=a-b M$

where, $\mathrm{N}$ is the cumulative number of earthquakes having magnitudes equal or larger than M, a and b are constants (Wiemer and Wyss, 2000). The coefficient of b value usually takes a value around 1.0 and characterizes the seismicity of the 
region (Utsu, 1999).

In this present study, Mc computation was performed for the time period 20132017. The most important reason for selecting this time period was the change of the magnitude type in the routine earthquake location procedure of RETMC. Magnitude type was changed to local magnitude Ml from the duration magnitude Md, in 2012. In the first few months of 2012 , both of the magnitudes were used in the earthquake catalogue of RETMC. However, an accurate robust catalogue with full Ml was succeeded mainly after 2013. Mc computation by using a maximum likelihood solution which is based on the maximum curvature method of (Wiemer and Wyss, 2000; Woessner and Wiemer, 2005) can be found in detail at the ZMAP code (Utsu, 1999; Wiemer and Katsumata, 1999). Maximum curvature is a fast and reliable estimate of $\mathrm{Mc}$, in order to define the point of the maximum curvature as a magnitude of completeness, by computing the first derivative of the frequency magnitude curve. This method matches the magnitude bin with the highest frequency of events in the non-cumulative frequency-magnitude distribution (Woessner and Wiemer, 2005). Figure 8 shows the frequencymagnitude distribution of the over-all catalog in the region. We obtained a magnitude completeness $\mathrm{Mc}=2.0$ and $\mathrm{b}$ value of $1.01 \pm 0.05$ for the catalog between the years 2013-2017 for the RETMC catalog.

Kalafat (2016) also computed the Mc values of Turkey and surrounding regions by using the KOERI catalogue in the time period 1975-2015. Due to lesser number of 


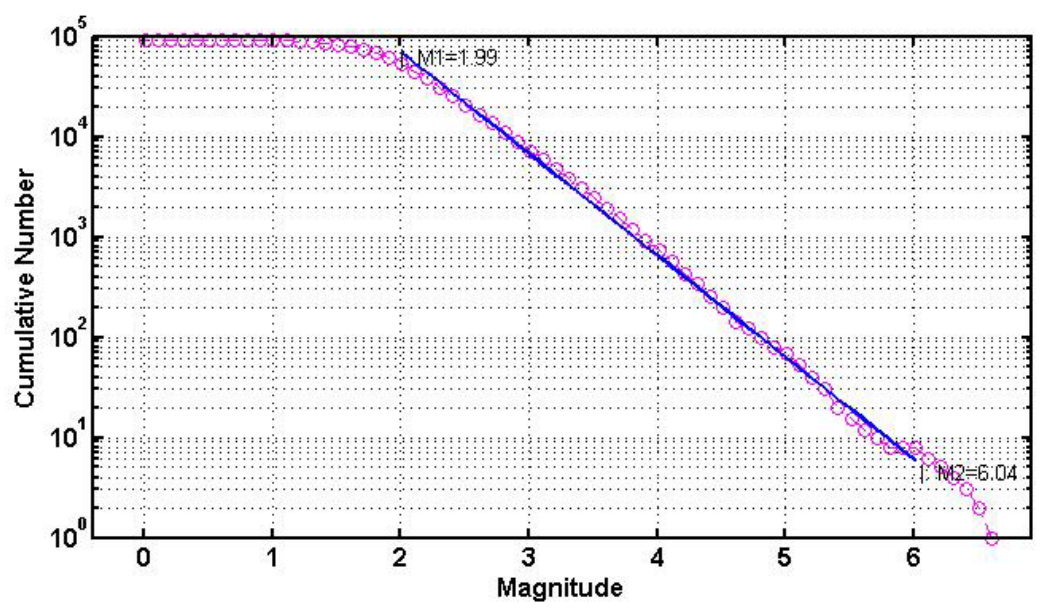

Figure 8. Frequency-magnitude distribution of the over-all catalog for the region $A$ (in Figure 2). Maximum Likelihood Solution for the catalog presenting the $\mathrm{Mc}=2, \mathrm{~b}$ value $=1.01 \pm 0.05$

Şekil 8. A Bölgesi için tüm kataloğa ait frekans-magnitüd dağılımı (Şekil 2). Katalog için Maximum Likelihood çözümü Mc=2, b-değeri=1.01 \pm 0.05 .

stations at that time period, they observed significantly higher Mc values in similar regions. Mc values were mainly changing between 2.6-2.9 for the selected regions. However, $\mathrm{Mc}$ has significantly decreased to $\mathrm{Mc}=2.0$ with the installation of recent stations in the region.

Figure 9 presents the Mc variation with time. It is known that the Mc value decreases after big shocks with the dense aftershock activity. Mc is almost uniform from beginning of 2013 up to the end of 2016. But just after 2017, first Mc value increases up to 2.6, then decreases sharply to 1.3 . This is a typical behavior of Mc, which is higher in the early part of an aftershock sequence due to the i) network is likely to be improved after the main shock ii) during the initial highest activity phase, due to the contamination of smaller earthquakes with the contamination of larger earthquake coda or because of the overwhelming 
workload (Wiemer and Katsumata, 1999). The effect of the recent series of earthquakes in the Aegean: onshore Biga peninsula Ayvacık - Çanakkale (February 2017; M5.2), offshore Lesvos - Karaburun (June 2017, M6.3) and offshore Bodrum - Kos (July 2017; M6.6) is quite visible on the Mc-time plot in Figure 9. In order to see these variations of Mc in detail, we presented the Mc variations for these three regions.

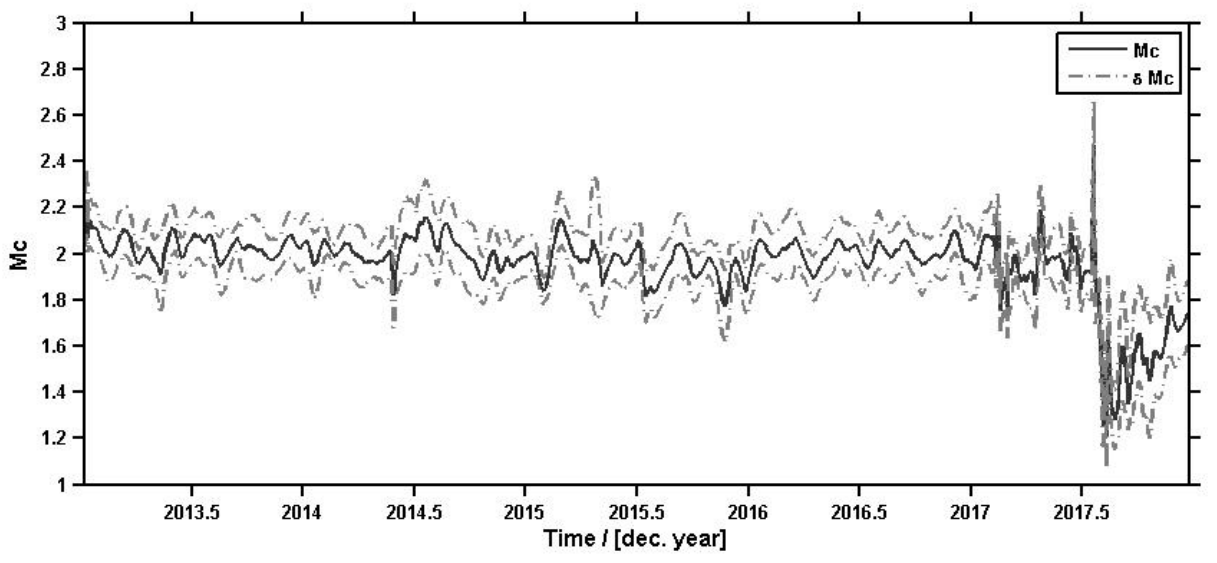

Figure 9. Mc versus time plot with anomalies after 2017 indicating the Aegean Sea earthquakes.

Şekil 9. Ege denizi depremleri sonrası değişikliği gösteren Mc - zaman değişim grafiği.

Mc in three different regions: Aegean Sea Earthquake Sequences in 2017

In order to understand the variation of Mc with time in Figure 9 we investigated the Mc variations in the region $B, C$ and $D$ in Figure 2. Ayvacık - Çanakkale in westernmost part of Turkey was struck by four moderate magnitude (Mw $5.2-5.4$ ) earthquakes in the beginning of 2017 . These were then followed by the Mw 6.3 Lesvos earthquake in the eastern Aegean in June 2017. This event caused severe 
shaking and extensive damage around Southern Lesvos. As a final event of these series, Bodrum - Kos earthquake Mw=6.6occurred in July 2017, near Kos island and the Bodrum peninsula. It was the largest instrumentally-recorded earthquake to occur within the Gulf of Gökova, one of the largest graben systems in the cost of southwest Turkey. This earthquake was widely felt across both Turkey and Greece, causing two fatalities and severe damage particularly on Kos island. In three months following the main shock, more than ten thousand earthquakes were reported by RETMC, 65 of which have magnitudes greater than 4.0.

Figure 10 shows the Mc variations for these three earthquake sequences in the time period 2017.01.01 to 2017.12 .31 , which is computed by using 5633,3044 , 12733 earthquakes, occurred in these regions, respectively (Figure 2). Maximum Likelihood Solution for the catalog presents the Magnitude of Completeness, $M c=2, b$-value=1.00 \pm 0.08 for Çanakkale-Ayvacık, Mc=2.1, b-value=0.97 \pm 0.04 for Karaburun-Lesvos, Mc=1.3, b-value=1.01 \pm 0.09 for Bodrum-Kos aftershock activities. The $b$ values are not significantly different from one another. But the value of Mc was different in Bodrum. Dense station distribution and closer stations to the main shock provide the detection of smaller earthquakes up to 0.3 and cause a smaller Mc value such as 1.3 in Bodrum. On the other hand, Mc variations are quite consistent with the anomalous behavior of the Mc versus time plot of the whole catalog in Figure 9.

Finally, as a last step to present the Mc variation in the region, a kriging algorithm has been used to obtain the magnitude completeness map of Turkey. It is one of the most flexible methods, when gridding data. It compensates for clustered data by giving less weight to the cluster in the overall prediction. Mc was estimated from 
the linear frequency-magnitude relation of the 200 closest earthquakes to grid nodes, spaced $10 \mathrm{~km}$ apart. The quality of all regional and local earthquake catalogs decrease with distance from the center of the network and coastlines and international borders are present as the obvious boundaries of this dissolution (Wiemer, 2001). Figure 11 shows the magnitude threshold map of Turkey and surrounding area according to the obtained earthquake magnitudes between 2013 and 2017.

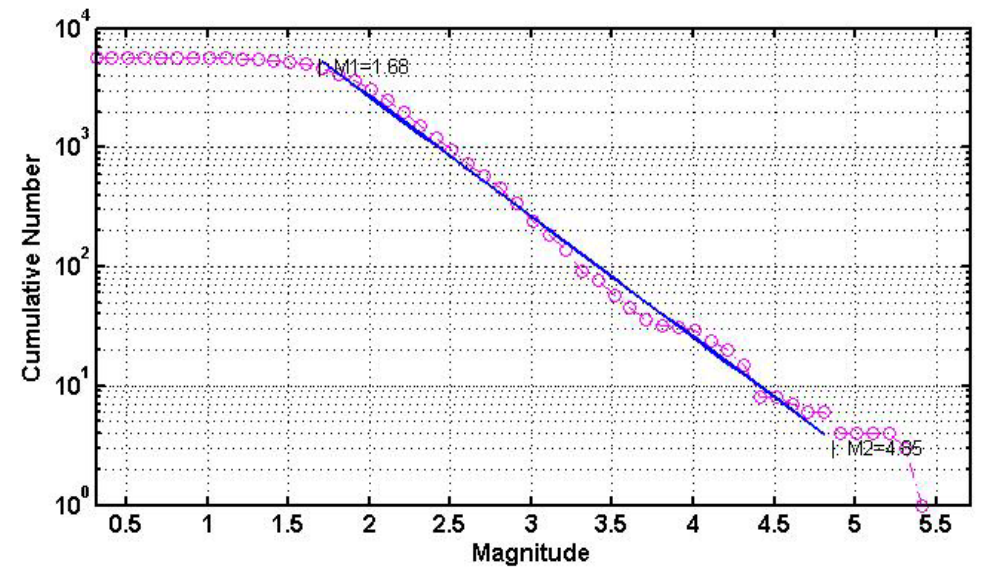

a)

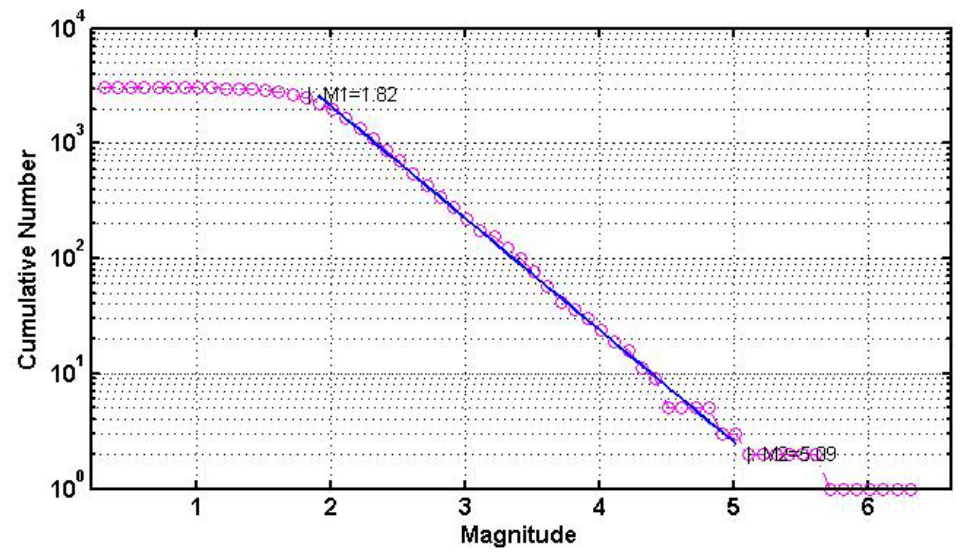

b) 


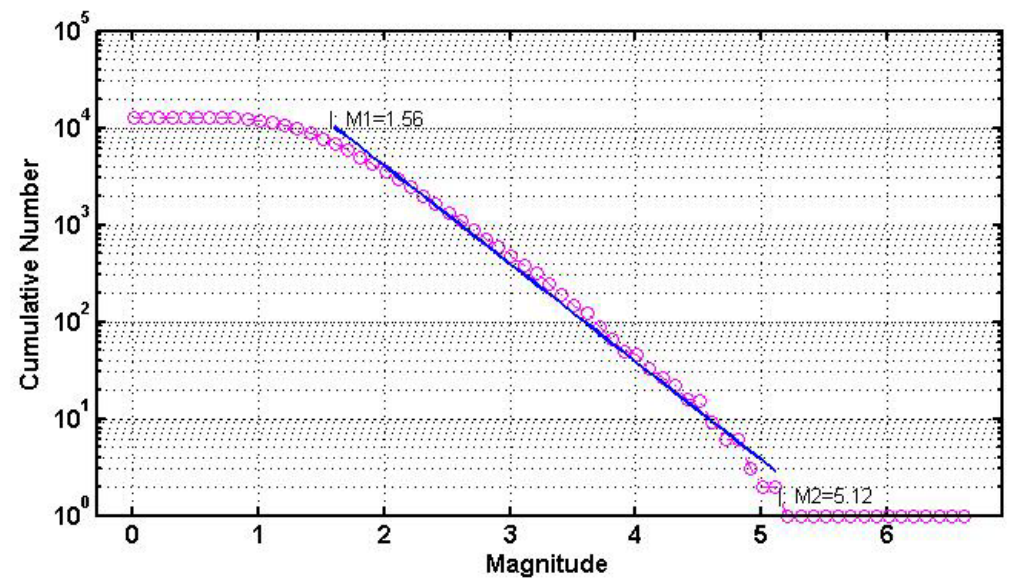

c)

Figure 10. Frequency-magnitude distribution for the a) Çanakkale-Ayvacık, b) Lesvos-Karaburun, and c) Bodrum earthquake activities (presented in the area B, $C, D$, respectively, enclosed in Figure 2).

Şekil 10. Frekans magnitüd dağıımı; a) Çanakkale - Ayvacık, b) LesvosKaraburun, c) Bodrum depremi aktiviteleri (Şekil 2'de B, C, D ile gösterilen alan).

Map (Figure 11) shows the variations of minimum detectable earthquake magnitude in the region. It can be seen that the minimum detectable earthquake magnitude is around $\mathrm{M}=2.0$ for entire Turkey and $\mathrm{Mc}$ is slightly heterogeneous in the catalog especially in the border regions. Magnitude threshold diminishes to $M=1.0$ in the regions with dense station distribution such as Southern, Western coasts of Turkey, in some parts of Central Anatolia and Marmara region. But it increases up to $M=2.5$ due to the sparse distribution of seismic stations especially in the Eastern part of Turkey and border regions. 


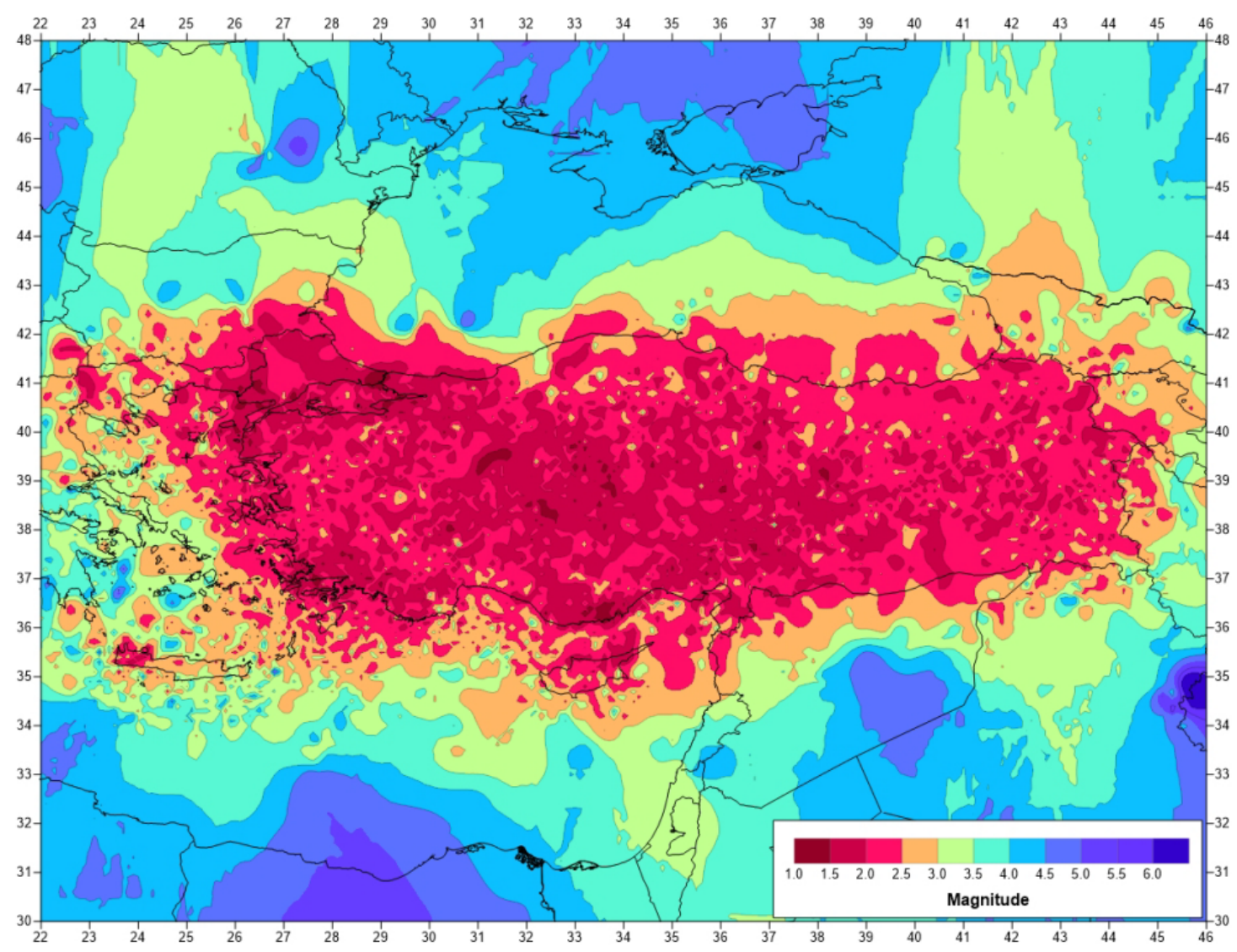

Figure11. Magnitude threshold map for Turkey and surrounding area computed by using the earthquakes in the time period 2013-2017.

Şekil 11. Türkiye ve etrafı için 2013-2017 yılları arasında meydana gelen depremleri kullanarak hesaplanan magnitüd eşik değer haritası.

\section{RESULTS AND DISCUSSIONS}

Earthquake catalogs are one of the most important outputs of seismology. Quality, consistency and the homogeneity of the catalogs must be well defined for the sake of reliability, performed by using these data. In this study, we submitted an overview on the operational procedures of RETMC, KOERI, which will be fulfilling the needs of RETMC data users. We presented a statistical analysis on RETMC 
earthquake catalog for the duration of 2013-2017 and showed the dynamic variations of Mc with respect to time and earthquakes sequences in the region. Magnitude of completeness was computed as $\mathrm{Mc}=2.0$ for almost all parts of Turkey with a b-value of $1.01 \pm 0.05$. Mc variation with time presented an almost constant value $\mathrm{Mc}=2.0$ up to the end of 2016 . However, it shows distinct variation after 2017 which indicates the effect of recent strong earthquake sequences in Aegean Sea in 2017. In order to see the variations in Mc we presented the differences in local earthquake sequences. We selected three significant aftershock sequences that have been occurred in the time period of this study. We observed compatible variations with the whole catalog. A general map of Mc variation for whole Turkey is also computed and presented in the study. Some areas in the eastern part of Turkey and the coast of Black Sea have higher Mc values up to $\sim 2.5$. Mc value decreases to $\sim 1.0$ in some areas with denser station distribution such as Marmara Sea, southern and western coasts of Turkey. RETMC is continuously enhancing its seismic network by installing new stations in order to reduce the minimum detectable magnitude level of earthquakes and increase the location precision.

\section{ACKNOWLEDGEMENTS}

We thank to all members of RETMC for making the seismic catalog available for research. M.D.C. acknowledges to Boğaziçi University, Scientific Research Projects (BAP) 9401P for supporting this work. Part of this project was funded by Boğaziçi University, Scientific Research Projects (BAP) with number 09T202P. 
Most of the figures were plotted using Generic Mapping Tools (Wessel et al, 2013). Seismicity analysis of this catalog was made by using the ZMAP software (Weimer, 2001) which uses a number of scripts written in Matlab (http://www.mathworks.com). We are thankful to editor in chief, Prof Dr. Mehmet Tekin Yürür, we also want to thank to Prof Dr. Hasan Sözbilir and an anonymous reviewer, for their constructive remarks to improve the manuscript.

\section{REFERENCES}

Altınok, Y., Ersoy., S., 2000. Tsunamis Observed on and Near the Turkish Coasts. Natural Hazards, 21, 185-205.

Altınok, Y., Alpar, B., Özer, N., Aykurt, H., 2011. Revision of the Tsunami Catalogue Affecting Turkish Coasts and Surrounding Regions. Natural hazards Earth System Science. 11, 273-293.

Ambraseys, N., 2009. Earthquakes in the Mediterranean and Middle East. (Ed.) Cambridge University Press, ISBN 978-0-521-87292-8, Cambridge.

Boğaziçi University Kandilli Observatory And Earthquake Research Institute. International Federation of Digital Seismograph Networks, Other/Seismic Network, doi:10.7914/SN/KO (https://doi.org/10.7914/SN/KO)

Cambaz, M.D., Mutlu, A.K., 2016. Regional moment tensor inversion for Earthquakes in Turkey and Its Surroundings: 2008-2015. Seismological Research Letters, 87, 5.

Chouliaras, G., 2009. Investigating the earthquake catalog of National Observatory of Athens. Nat. Hazard Earth Syst. Sci., 9, 905-912. 
Fettahoğlu, K., 2012. Rasathane-I Amirenin Kuruluşu ve Faaliyetleri (1868-1922). Yüksek Lisans Tezi, Marmara Üniversitesi.

Gulia, L., Wiemer, S., Wyss, M., 2012. Catalog artifacts and quality controls, Community Online Resource for Statistical Seismicity Analysis, doi:10.5078/corssa-93722864.

Gutenberg, R., Richter, C.F., 1944. Frequency of earthquakes in California, Bull. Seism. Soc. Am.34,185-188.

Heidarzadeh, M., Necmioglu, Ö., Ishibe, T., Yalçıner, A., 2017. Bodrum-Kos (Turkey-Greece) Mw 6.6 earthquake and tsunami of 20 July 2017: a test for the Mediterranean tsunami warning system. Geoscience Letters, 4:31.

Ishimoto, M., lida, K., 1939. Observations of earthquakes registered with the microseismograph constructed recently. Bull. Earthquake Res. Inst.17,443478.

Kadirioğlu, F.T., Kartal, R.F., Kılıç, T., Kalafat, D., Duman, T.Y., Azak, T.E., Özalp, S., Emre, Ö., 2016. An improved earthquake catalogue $(M \geq 4.0)$ for Turkey and its near vicinity (1900-2012). Bulletin of Earthquake Engineering Official Publication of the European Association for Earthquake Engineering, ISSN 1570-761X, DOI 10.1007/S10518-016-0064-8.

Kalafat, D., Gürbüz, C., and Üçer, B., 1987. Batı Türkiye'de Kabuk ve Üst Manto Yapısının Araştırılması. Deprem Araştırma Bülteni 59, 43-64.

Kalafat, D., Kara, M., Kekovalı, K., Püskülcü, S., Güneş, Y., 2003. Türkiye ve

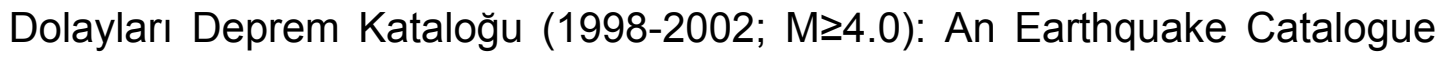
for Turkey and Surrounding Area, Boğaziçi Üniversitesi Yayınları No=802, 135 s. (in Turkish).

Kalafat, D., Güneş, Y., Kara, M., Deniz, P., Garip, K., Kekovalı, K., Kuleli, S., Gülen, L., Yılmazer, M., Özel, N., 2006. Bütünleştirilmiş Homojen Türkiye Deprem Kataloğu (1900-2005; $M \geq 4.0$ ): A revised and extended earthquake 


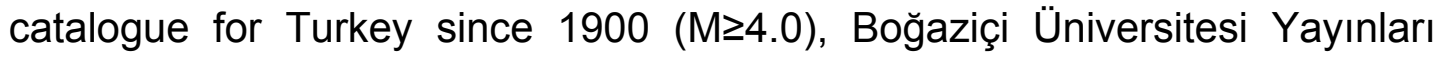
No=977, 558p., Bebek, İstanbul.

Kalafat, D., Kekovalı, K., Güneş, Y., Yılmazer, M., Kara, M., Deniz, P., Berberoğlu, M., 2009. Türkiye ve Çevresi Faylanma-Kaynak Parametreleri (MT) Kataloğu (1938-2008), Boğaziçi Üniversitesi Yayınları No=1026, 43p., Bebek, İstanbul.

Kalafat, D., Güneş, Y., Kekovalı, K., Kara, M., Deniz, P., Yılmazer, M., 2011. Bütünleştirilmiş Homojen Türkiye Deprem Kataloğu. Boğaziçi Universitesi, Bebek, İstanbul.

Kalafat D., 2016. Statistical Evaluation of Turkey Earthquake Data (1900-2015): A Case study. Eastern Anatolian Journal of Science. Vol2. 14-36.

Kalafat, D., 2017. Türkiye'de Sismik Gözlem Ağlarının Gelişimi, (Tema

Konuşması), 4. Ulusal Deprem Mühendisliği Konferansı, 11-13 Ekim 2017, Eskişehir.

Kekovali, K., 2009. Patlatma Kaynaklı Verilerin Deprem Verilerinden Ayrımına Yönelik Spektral Yöntemlerin Uygulanabilirliği ve Patlatma Veri tabanı Katalog Hazırlığı. Boğaziçi University, Scientific Research Projects (BAP) Number 09T202P.

Koçyiğit, A., Ünay, E., Saraç, G., 2000. Episodic Graben Formation and Extensional Neotectonic Regime in West Central Anatolia and the Isparta Angle: A Case Study in the Akşehir-Afyon Graben, Turkey. Geological Society of London 173, pp. 405-421.

Konstantinos, M.L., Karakostas, V., Eleftheria, G., Papadimitriou, E., Adamaki, A.K., Tan, O., İnan, S., 2013. A Homogeneous Earthquake Catalog for Western Turkey and Magnitude of Completeness Determination. Bull. Seismol. Soc. Am. 103 (5): 2739-2751. 
Lee, W.H.K., Lahr, J.C., 1972. HYPO71: A Computer Program for Determining Hypocenter, Magnitude and First Motion Pattern of Local Earthquakes Open File Report, U. S. Geological Survey, 100 pp.

Lomax, A., Michelini, A., 2012. Tsunami Early Warning Within Five Minutes. Pure Appl. Geophys. 170 (2013), 1385-1395.

Lorito, S., Tiberti, M.M., Basili, R., Piatanesi, A., Valensise, G., 2007. EarthquakeGenerated Tsunamis in the Mediterranean Sea: Scenarios of Potential Threats to Southern Italy. Journal of Geophysical Research, Vol. 113, B01301.

Louderback, G. D., 1948. Giovanni Agamennone, Bulletin of the Seismological Society of America (1948) 38 (4): 289-290.

Lu, Y., Stehly, L., Paul, A., and AlpArray Working Group., 2018. High-resolution surface wave tomography of the European crust and uppermost mantle from ambient seismic noise. Geophys. J. Int., 214, 1136-1150.

Mignan, A., Woessner, J., 2012. Estimating the magnitude of completeness for earthquake catalogs. Community Online Resource for Statistical Seismicity Analysis, doi:10.5078/corssa-00180805.

Necmioglu, Ö., Özel, N.M., 2015. Earthquake Scenario-Based Tsunami Wave Heights in the Eastern Mediterranean and Connected Seas. Pure and Applied Geophysics, Volume 172, Issue 12 (2015), Page 3617-3638.

Soloviev, S. L., Solovieva, O.N., Go, C.N., Kim, K.S., Shchetnikov, N.A. (Eds.) 2000. Tsunamis in the Mediterranean Sea - 2000 B.C.-2000 A.D., Kluwer Academic Publishers, 237 pp.

Stampfli, GM, 2000. Tethyan Oceans, From: Bozkurt E., Winchester, J. A. and Piper, J. D.A., Tectonic and Magmatism in Turkey and the Surrounding Area. Geological Society, London, Special Publications 173, pp. 1-23. 
Tan, O, Tapırdamaz, MC, Yörük, A., 2008. The Earthquake Catalogues for Turkey. Turkish Journal of Earth Sciences, 17, No.2, 405-418.

Tinti, S., Armigliato, A., Pagnoni, G., and Zaniboni, F., 2005. Scenarios of Giant Tsunamis of Tectonic Origin in the Mediterranean. ISET Journal of Earthquake Technology, 42, 171- 188.

Weber, B., Becker, J., Hanka, W., Heinloo, A., Hoffmann, M., Kraft, T., Pahlke, D., Reinhardt, J., Thoms, H., 2007. SeisComP3 - automatic and interactive real time data processing. EGU General Assembly, Vol. 9, No. 09219.

Wessel, P., Smith, W.H.F, Scharroo, R., Luis J. F, Wobbe, F., 2013. Generic mapping tools: improved version released. EOS Trans AGU 94(45):409-410.

Wiemer, S., Katsumata, K., 1999. Spatial variability of seismicity parameters in aftershock zones. J.Geophys. Res. 104, p. 13135-13151.

Wiemer, S., Baer M., 2000. Mapping and removing quarry blast events from seismicity catalogs. Bull. Seism. Soc. Am. 90, 525-530.

Wiemer, S., 2001. A Software package to Analyze Seismicity: ZMAP. Seismological Research Letters, Volume 72, Number 2, March/April 2001.

Wiemer, S., Wyss, M., 2000. Minimum magnitude of complete reporting in earthquake catalogs: Examples from Alaska, the Western United States, and Japan. Bull. Seismol. Soc. Am. 90, 859-869.

Woessner, J., Wiemer, S., 2005. Assessing the Quality of Earthquake Catalogues: Estimating the Magnitude of Completeness and Its Uncertainty. Bull. Seism. Soc. Am. 95, 684-698.

Utsu, T., 1999. Representation and Analysis of the Earthquake Size Distribution: A Historical Review and Some New Approaches. Pure Appl. Geophys. 155, p.509-535. 
Yalçıner, A.C., Pelinovsky, E., Talıpova, T., Kurkın, A., Kozelkov A., and Zaitsev, A., 2004. Tsunami in the Black Sea: Comparison of the Historical, Instrumental and Numerical Data. Journal of Geophysical Research, 109.

Yalçıner, A.C., Annunziato, A., Papadopoulos, G., Dogan, G. G., Güler, H. G., Çakır, T. E., Sözdinler, C. O., Ulutas, E., Arikawa, T., Suzen, L., Kanoglu, U., Güler, I., Probst, P., Synolakis, C., 2017. The 20th July 2017 (22:31 UTC) Bodrum/Kos earthquake and tsunami; post tsunami field survey report. http://users.metu.edu.tr/yalciner/july-21-2017-tsunami-report/Report-FieldSurvey-of-July-20-2017-Bodrum-Kos-Tsunami.pdf.

Yılmaz, Y., Yiğitbaş, E., Yıldırım, M., 1987. Güneydoğu Anadolu'da Triyas Sonu Tektonizması ve Bunun Jeolojik Anlamı. Türkiye 7. Petrol Kongresi Bildiriler Kitabı, pp. 65-77, Ankara.

Yılmazer, M., 2012. zSacWin: A Rapid Earthquake Processing and Archiving System, User Guide v1.0. December 2012. Supported by the Research Fund of the Boğaziçi University Project Number 5725P.

Yolsal-Çevikbilen, S. and T. Taymaz, 2012. Earthquake Source Parameters Along the Hellenic Subduction Zone and Numerical Simulations of Historical Tsunamis in the Eastern Mediterranean. Tectonophysics, 536-537, 61-100. 